\title{
Analysis of Productivity Controlling for Adjacent CBM Wells in Mining Subsidence Area: a Case in the Fanzhuang Block, Southern Qinshui Basin, China
}

\author{
ZHU Qingzhong ${ }^{1, a}$, ZHANG Zhengguang ${ }^{* 2, b}$, Zhang Wensheng ${ }^{1, c}$, \\ WU Congcong ${ }^{2}$, ZHANG Yongping ${ }^{1}$, LI Yangyang ${ }^{2}$, HU Qiujia ${ }^{1}$ \\ ${ }^{1}$ PetroChina Huabei Oilfield Company, Exploration and Development Research Institute, Renqiu \\ 02552, China
}

${ }^{2}$ Key Laboratory of Coalbed Methane Resources and Reservoir Formation (Ministry of Education of China), China University of Mining and Technology (CUMT), Xuzhou, Jiangsu 221008, China

acongwu0510@163.com, 흐engguang0411@163.com, ‘Q2279645582@163.com

Key words: mining subsidence area; coalbed methane; positive and negative effect; permeability; gas content

Abstract. In order to analyze the productivity influence of mining subsidence area to adjacent coal seam gas wells, the paper studied physical properties and production characteristics of CBM wells in southwest Fanzhuang block. With changes of distance to mining subsidence area, distribution characteristics of gas content and permeability were expounded, variation character of gas production, water production of CBM wells were also analyzed. The mining subsidence area increased permeability of adjacent coal seam, meantime, reduced the gas content of coal seams, the coupling of positive and negative effects were main reasons for CBM production variability. The results indicates that with the increasing distance to mining subsidence area, the gas content increased gradually, and permeability decreased afterwards stable, the permeability achieved maximum value in depressurized zone; according to the production characteristics of CBM wells and permeability variation characteristics of adjacent coal seam, the around area of goaf was divided into zone I (pressure relief zone), zone II (intense interface area), zone III (weak interface area), zone IV (original coal district). Zone II and zone III are the most favorable area for high efficient development of CBM wells.

\section{Introduction}

As one of the clean energy, coal bed methane(CBM) has been put more and more attention in recent years. Since the mid-1980s the U.S. began genuine exploitation and utilization, the world set off the upsurge. According to extensive fundamental theoretical research, the researchers of U.S. recognized that $\mathrm{CBM}$ productive is a process of drainage-depressurizing-desorptiondiffusion-seepage (R.M.Flores, 1998), they proposed reservoir excitation technique(Law D. et al.,2002; Scott R.,2002), like fracturing, gas injecting and so on. They also developed numerical simulation of CBM reservoir and gained good application, such as stochastic geostatistical algorithms were applied to predict remaining gas in Blue creek (Karacan, 2013). Now the United States has formed the world's most mature and complete system for CBM development. China also done a lot of research on CBM, and now has developed gas drainage technology, integrated coal mining and gas extraction, it included current seam gas drainage, protective seam extraction and goaf gas extraction(Qin et al.,2012); the development mode of integrated coal mining and gas extraction(Fan et al.,2014); "Huainan mode" aimed at high-gas prevention and control(Yuan,2006; Cheng et al.,2007; Zhao,2007); "Jincheng mode" aimed at stereo gas drainage(Wu,2011). However, there are seldom analysis for productivity characteristics near mining subsidence area. In view of this, based on productivity characteristics of CBM wells near mining subsidence area in southwest Fanzhuang block, analyzed gas content and permeability properties of adjacent seams, and illustrates the mining subsidence area effect on gas production and water production of near CBM wells. 


\section{Geological Conditions of Fanzhuang Block}

The Fanzhuang block is located in Guxian-Jincheng monoclonal zone, and there are Sitou normal fault, Yaogou normal fault zone, Chenghouyao normal fault in its western side. Marginal faults are mainly north-dipping and internal faults are mainly south-dipping, fault throw for $70 \mathrm{~m}$ to $300 \mathrm{~m}$. Eastern of Fanzhuang block develops NNE faults, like Shimen normal fault, Fudi normal fault, and skew with Sitou normal fault, fault throw generally about $50 \mathrm{~m}$ to $105 \mathrm{~m}$. Guxian region developed NW-plunging nose structure, it can be divided into Guxian nose flexure zone and Bucun-Beiliu nose flexure zone.

Fanzhuang block exploration and research level were relatively high, with a total gas-bearing area of $398.23 \mathrm{~km}^{2}$, total resources is $1043.3 \times 10^{8} \mathrm{~m}^{3}$, the proved area of gas-bearing in the Fanzhuang block is $182.22 \mathrm{~km}^{2}$ and the proved reserves is $352.26 \times 10^{8} \mathrm{~m}^{3}$. The main coal-bearing strata of Fanzhuang block is No.3 coal in Shanxi formation $\left(\mathrm{P}_{1 \mathrm{~s}}\right)$ of lower Permian system. The metamorphic grade is high and it belong to anthracite coal seam, with moderately burial depth ( $480 \mathrm{~m}$ to $550 \mathrm{~m})$, larger thickness $(5 \mathrm{~m}$ to $6.4 \mathrm{~m})$. The horizontal distribution is continuous and steady, formation dip generally $2^{\circ}$. The coalbed gas content is about $14 \mathrm{~m}^{3} / \mathrm{t}$ to $26 \mathrm{~m}^{3} / \mathrm{t}$ and the coalbed gas saturation is $71 \%$ to $98 \%$, this would help coalbed methane degraded and desorbed, all these characteristics are benefit to CBM development. Permeability in this region are relatively poor, permeability of injection/draw down testing are $(0.035 \sim 0.514) \times 10^{-3} \mu \mathrm{m}^{2}(\mathrm{Li}$ et al.,2011; Wang et al.,2004;Yao,2009; Lin et al.,2012; Hu et al.,2012;Cao,2005). Currently there are more than 1100 wells and annual yield were $5.7 \times 10^{9} \mathrm{~m}^{3}$. South Fanzhuang block mainly include Pingshang mine, Qudi mine and Duanshi mine, and all of them mining No.3 coal seam. Pingshang coal mining limited company, namely, previous Pingshang coal mine in Qinshui county production capacity is $9 \times 10^{5} \mathrm{t} / \mathrm{a}$, and $4.5 \times 10^{5} \mathrm{t} / \mathrm{a}$ of Qudi coal mine, $1.2 \times 10^{6} \mathrm{t} / \mathrm{a}$. The location of coal mines and CBM wells are shown in Figure 1.

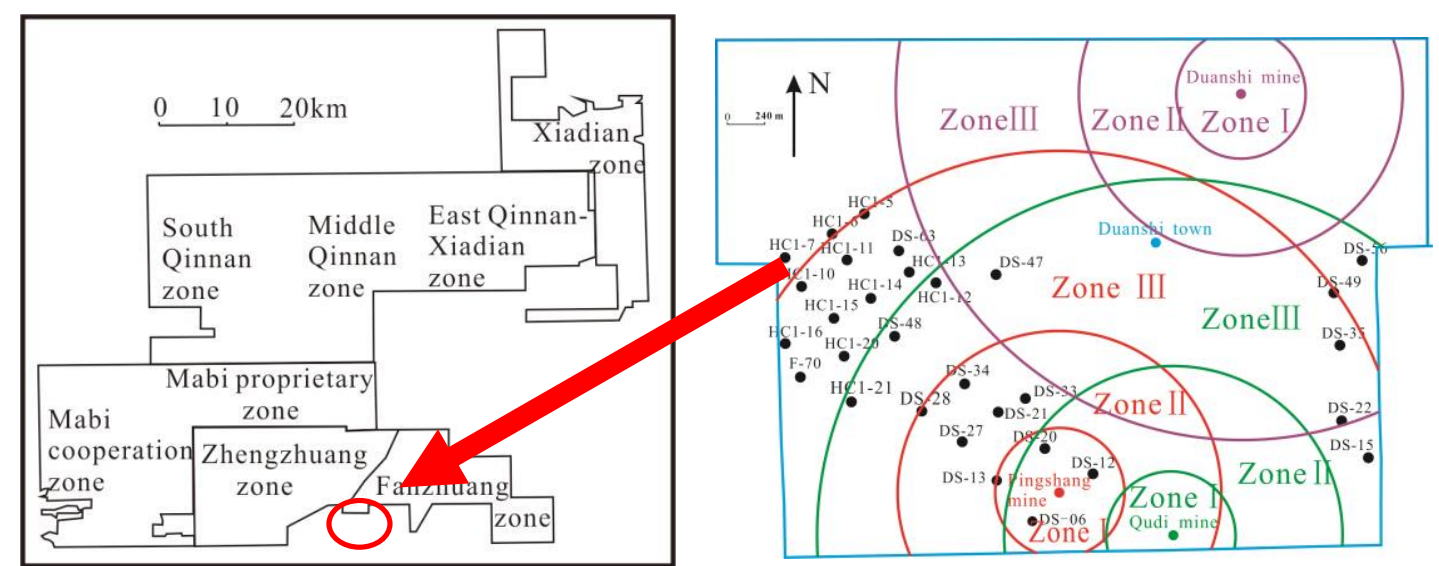

Figure 1. Location of study area and wells relative distribution

\section{Research Methods}

The paper selected 30 CBM wells near mining subsidence area as research objects(Fig.1), there are distributed in Pingshang mine, Qudi mine and Duanshi mine, their geological settings are roughly the same, the distance of wells to mining subsidence area is between $241.07 \mathrm{~m}$ to $3301.64 \mathrm{~m}$. gas-producing duration generally between 3 years to 5 years, water-producing duration refer to consistent output time during production process. According to productivity characteristics of CBM wells near mining subsidence area and gas content, permeability, the rules of mining subsidence areas in gas content, permeability of near coal seams and in productivity effect law were elaborated, productivity control mode of CBM wells near mining subsidence areas were also proposed.

\section{Productivity Effect of Mining Subsidence Area on CBM Wells}

During coal mining process, it will cause overlying strata collapse and movement, then bring plenty 
of cracks. Cracks generally can be classified as "vertical three zone" and "horizon three zone", namely, from downwards to upwards can divided into caving, fracturing and bending zone along right angles to the direction of roof of mining subsidence area; it also can divided into coal seam supporting affected zone, strata separation area and reconsolidated area along with the direction of mining subsidence area. With the working face advanced, "vertical three zone" and "horizon three zone" moved forward dynamically. Stresses of mining area presented with pressure relief state, and coal seams shown effect of pressure-relief and permeability increasing with the increases of coal seam cracks (Qian et al.,1998; Sun et al.,1999; Wu et al.2007;wu et al.,2008;Hu et al.,2009).

Coal mining caused pressure relief, permeability increased and gas content decreased, thus had different impacts on productivity of CBM wells. With the increasing distance from mining subsidence area, different results were presented of CBM wells productivity.

\section{Permeability Features of CBM Wells Near Mining Subsidence area}

Coal mining can expands original fracture in coal seams and produces mixed sizes of new fractures, then substantially improve permeability of coal seam. With the increasing distance from mining subsidence area, the effect of pressure-relief and permeability increasing on near coal reservoirs is gradually decreased.

From figure 2-a and figure 2-b, With the increasing distance from mining subsidence area, the permeability of coal seams presented decreased first and then tended to be stable; permeability shown increases first and then decreases in figure 2-c, the main reason is the distance between CBM wells and Duanshi mine is too far compared with Pingshan mine and Qudi mine, and coal seams has little effect on permeability; figure 2-d shows that the relationship between permeability and the average distance from three coal mines to CBM wells, it can be seen that permeability represents the tendency of decreases first then stable with the increases of average distance. This is because that with the increases distance to mining subsidence area, pressure-relief and permeability increasing impacts reduces gradually, and the influence to permeability of coal reservoirs is fading too. Aimed at figure 2-a, 2-b and 2-d, it can be seen that influence boundary of mining subsidence area to coal reservoirs ranges from $1600 \mathrm{~m}$ to $2200 \mathrm{~m}$, and this paper take $2200 \mathrm{~m}$ as boundary area.

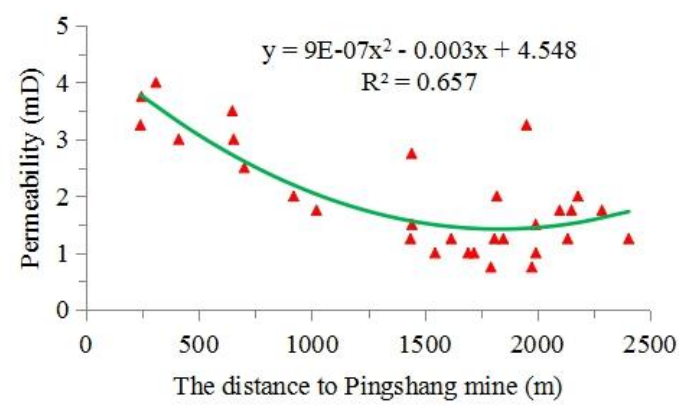

(a)

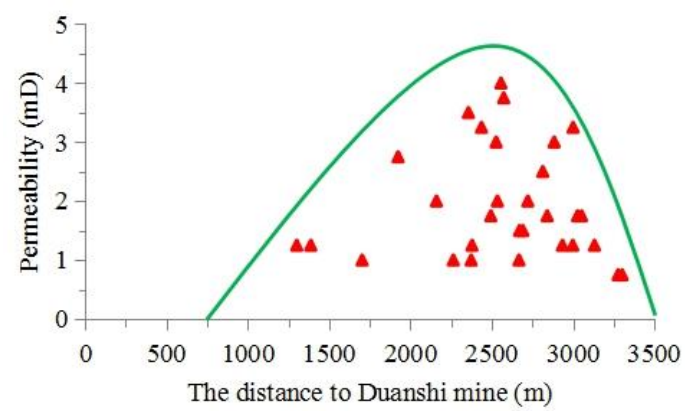

(c)

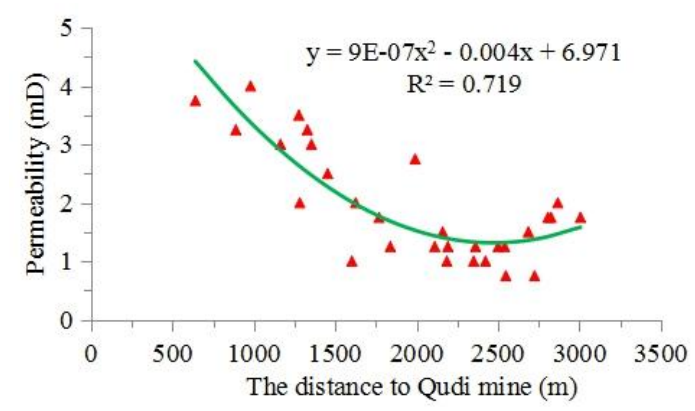

(b)

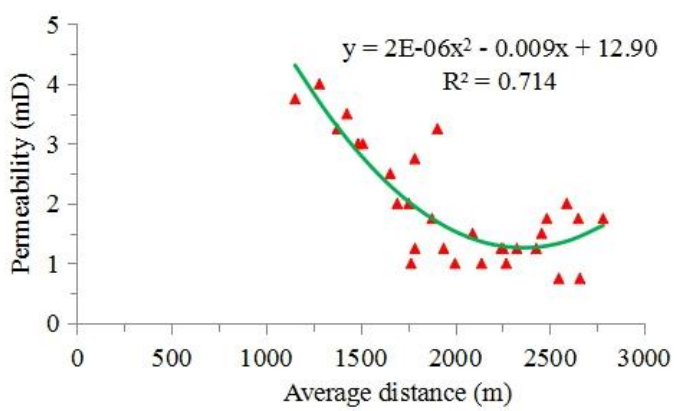

(d)

Figure 2. The relationship between the distance to mining subsidence area and permeability 


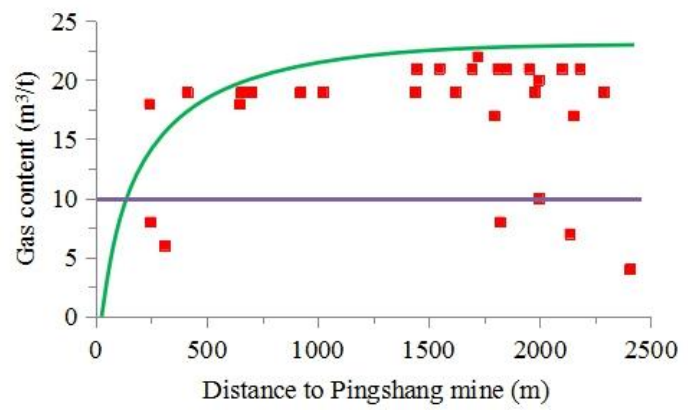

(a)

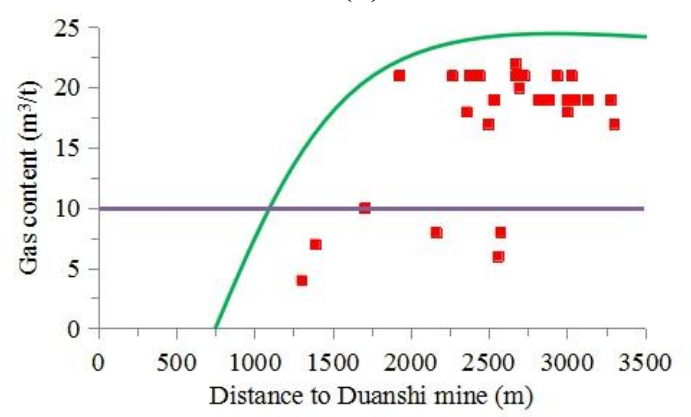

(c)

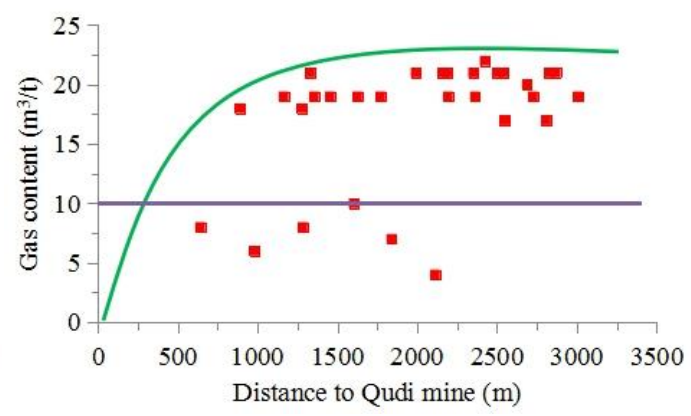

(b)

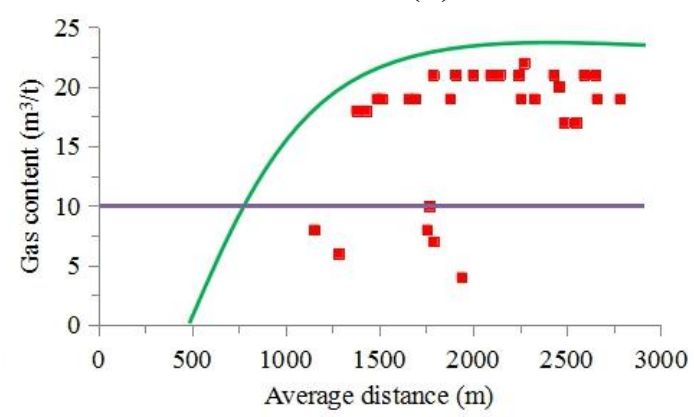

(d)

Figure 3. The relationship between the distance to mining subsidence area and gas content

Gas Content Features of CBM Wells near Mining Subsidence Area. After coal mining, geostress balance were destroyed, then caused stress release of roof, floor rocks and surrounding coal seams, expanded width and length of fractures, leading to pore-fracture increased and permeability improved, hence increased gas transporting ability of migration pathways(Jia et al.,2016). In this process, dynamic equilibrium of CBM in coal reservoirs was disturbed, then CBM migrated to mining subsidence area and low pressure area. CBM contents fluctuate different with distance from mining subsidence area.

Seeing from figure 3, gas content in coal seams presents raises afterwards steady with the increase distance to mining subsidence area. From $200 \mathrm{~m}$ to $1000 \mathrm{~m}$, the gas content fluctuate between $5 \mathrm{~m}^{3} / \mathrm{t}$ to $15 \mathrm{~m}^{3} / \mathrm{t}$; gas content remains at about $20 \mathrm{~m}^{3} / \mathrm{t}$ as the distance is more than $2000 \mathrm{~m}$ (fig.3-a, fig.3-b, fig.3-c). As is show in figure $3-\mathrm{d}$, in the range of $1000 \mathrm{~m}$ to $2000 \mathrm{~m}$, gas contents was higher than $10 \mathrm{~m}^{3} / \mathrm{t}$. The reason is disturbance reduces with the increases distance to mining subsidence area, it dropped off pore-fracture of roof, floor and surrounding adjacent coal seams, and decreased fracture flow capacity and effusion ability of CBM. Therefore, gas content increases with the increases of distance to mining subsidence area.

Gas-production Features of CBM wells near Mining Subsidence Area. With the increases distance to mining subsidence area, the permeability of coal reservoirs improved and caused lower starting pressure gradient, this is beneficial for gas migration and CBM production, and the function called positive effect; meanwhile, the increases of permeability will help CBM emission and caused gas content decreased, this is unfavourable to raising production of CBM wells, the function called negative effect. Gas production of CBM wells in south Fanzhuang block is the integrated effect from three mining subsidence area, as well as the combination of positive and negative effect. 


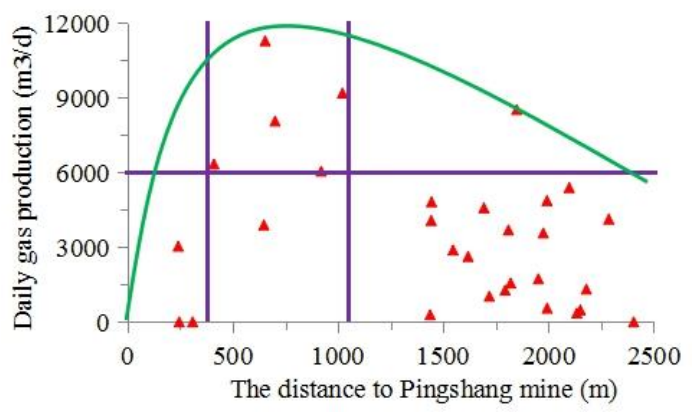

(a)

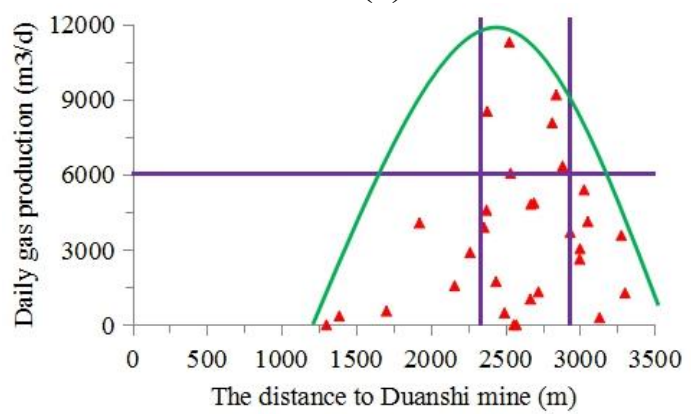

(c)

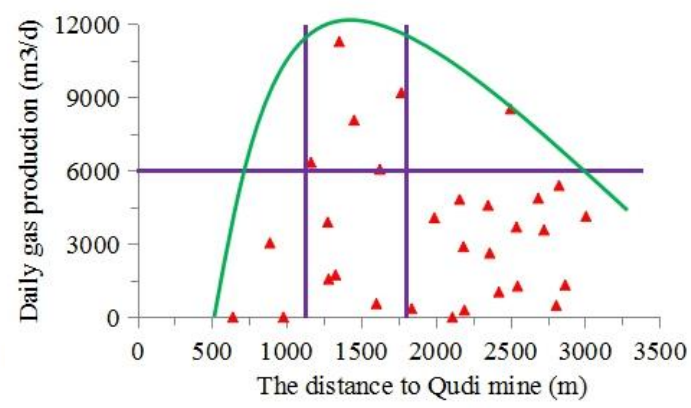

(b)

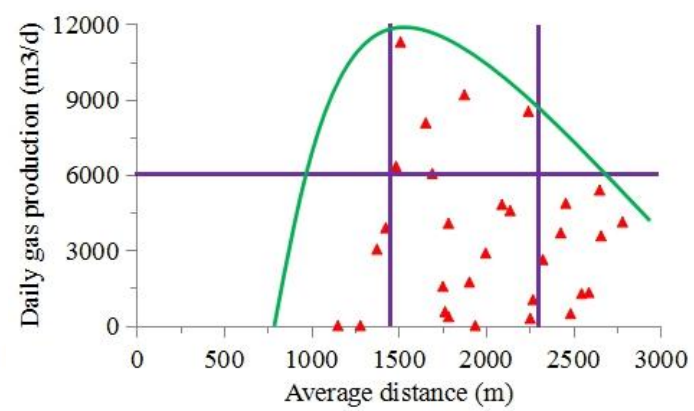

(d)

Figure 4. The relationship between the distance to old coal mine and the average daily gas production

Due to the distance of Duanshi mine is far from CBM wells than Pingshang mine and Qudi mine, it has no significant effect on CBM wells; figure 4-a, figure 4-b and figure 4-d display a tendency of increased firstly and then decreased for daily gas production of CBM wells, daily gas production of CBM wells over $6000 \mathrm{~m}^{3} / \mathrm{d}$ has a distance of $400 \mathrm{~m}$ to $1000 \mathrm{~m}$ to Pingshang mine, and has a distance of $1100 \mathrm{~m}$ to $1800 \mathrm{~m}$ to Qudi mine; while the distance to closest CBM well is over $1300 \mathrm{~m}$ for Duanshi mine, so trend chart of figure 4-c is quite different from the other three charts and it cannot completely reflect the relationship between mining subsidence area and CBM wells. The greater distance, the less the effect to CBM wells, and the lower contributions to well productivity. Daily gas production of CBM wells higher than $6000 \mathrm{~m}^{3} / \mathrm{d}$ is closest to mining subsidence area of Pingshang mine, followed by coal mining area of Qudi mine. As is shown in figure4-a, combined with physical analysis, the distance of $400 \mathrm{~m}$ to $1000 \mathrm{~m}$ from CBM wells to Pingshang mining subsidence area is called zone II, namely, intense interface region, and CBM wells in this region has highest daily gas production; the distance to mining subsidence area within $400 \mathrm{~m}$ is called zone I ,namely, distressed zone, this region lower CBM yields and even it may be zero. As we mentioned, $2200 \mathrm{~m}$ is affecting boundary of mining subsidence area, so the distance of $1000 \mathrm{~m}$ to $2200 \mathrm{~m}$ is regarded as zone III, namely, weak interface region, CBM yields in this region is lower than intense interface region and higher than original zone. The distance to original zone over $2200 \mathrm{~m}$ is called zone IV, and zone IV has minimal impact on coal reservoir. As seeing in figure 4, CBM daily gas production chosen by 30 CBM wells in this paper was $3519.47 \mathrm{~m}^{3} / \mathrm{d}$. daily gas production in most of zone I was $0 \mathrm{~m}^{3} / \mathrm{d}$; zone II had highest daily gas yield of $7469.12 \mathrm{~m}^{3} / \mathrm{d}$; daily gas production of CBM wells in zone III was $2821.37 \mathrm{~m}^{3} / \mathrm{d}$; zone IV with a daily gas production of $2062.23 \mathrm{~m}^{3} / \mathrm{d}$.

Water-producing Features of CBM Wells near Mining Subsidence Area. Water-discharging and pressure-dropping is an important step in CBM production, and water yield is an important reference index during drainaging of CBM wells. Excessive daily water production will caused sand spouting and pulverized coal output, even appeared the phenomenon of water block; less water production will caused extension of construction period and investment increased, then failed to obtain maximized industrial benefits. Through analysis of water production characteristics of CBM wells near mining subsidence area in southern Fanzhuang block, illustrate the relationship between 4 division region near mining subsidence area and daily water production, this provide reference for production guidance to CBM wells near mining subsidence area. 


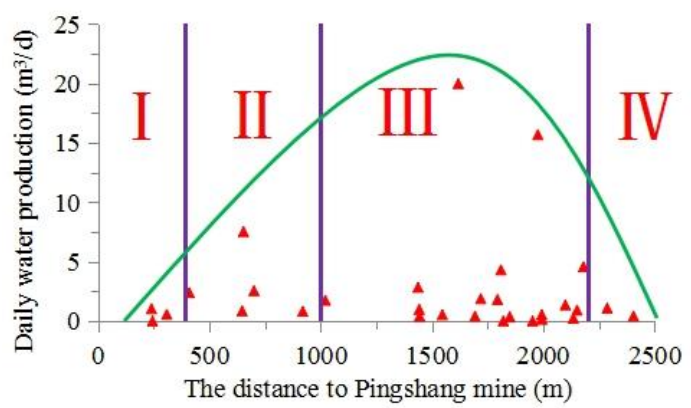

(a)

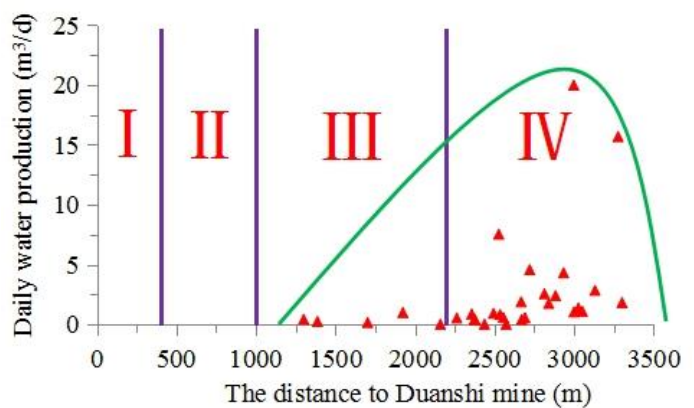

(c)

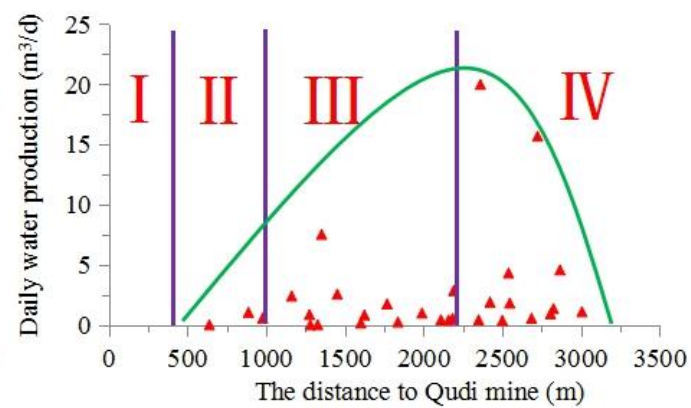

(b)

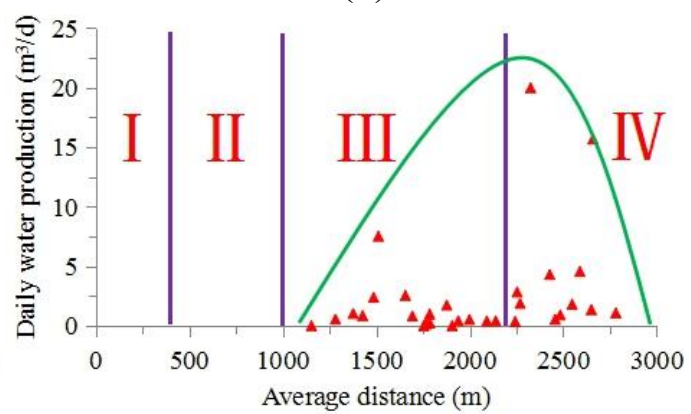

(d)

Fig.5 The relationship between the distance to old coal mine area and the average daily water production

From figure 5, daily water-production of CBM wells increased gradually with the increased distance to mining subsidence area within mining influence area(zone I 、zone II 、zone III). Figure 5-a shows daily water production lower than $1.2 \mathrm{~m}^{3} / \mathrm{d}$ even down to zero in zone I; water-producing duration in zone I was between $0 \mathrm{~d}$ to $385 \mathrm{~d}$ and the average water-producing duration was $187.25 \mathrm{~d}$.

In zone II , daily water-production was between $0 \mathrm{~m}^{3} / \mathrm{d}$ to $7.6 \mathrm{~m}^{3} / \mathrm{d}$ and the average water-production was $2.6 \mathrm{~m}^{3} / \mathrm{d}$, water-producing duration was between $71 \mathrm{~d}$ to $574 \mathrm{~d}$ and the average water-producing duration was $313.5 \mathrm{~d}$. water-producing duration in zone II was longer than zone I obviously (figure 5 -a and 5-b).

In zone III, daily water-production was between $0 \mathrm{~m}^{3} / \mathrm{d}$ to $20 \mathrm{~m}^{3} / \mathrm{d}$ and the average water-production was $3 \mathrm{~m}^{3} / \mathrm{d}$, water-producing duration was between $0 \mathrm{~d}$ to $1816 \mathrm{~d}$ and the average water-producing duration was $1095.05 \mathrm{~d}$. That reservoir physical property had changed near mining subsidence area was the prime cause. Especially the regular changeable permeability led to fundamentally change of water content in coal reservoir. Figure 5-b and 5-c also reveals daily water-production increased gradually with the increased distance to mining subsidence area. Because of mining subsidence area in Qudi mine and Duanshi mine has a longer distance to these CBM wells than Pingshang mine, namely, mining subsidence area in Pingshang mine has the greater impact on water-production. Therefore, daily water-production features has been stated by the example of figure 5 -a.

Typical Production Curve of CBM wells near Mining Subsidence Area. Production curve is the concrete performing form of CBM wells production, gas-water production features can displayed vividly in production curve, it have the important referential significance to be used to assess production potential, enhance production systems and improve productivity. The following 4 wells are the representative curves of 4 zones. The production curve is consists of daily gas-production, daily water-production, total gas-production and total water-production. 


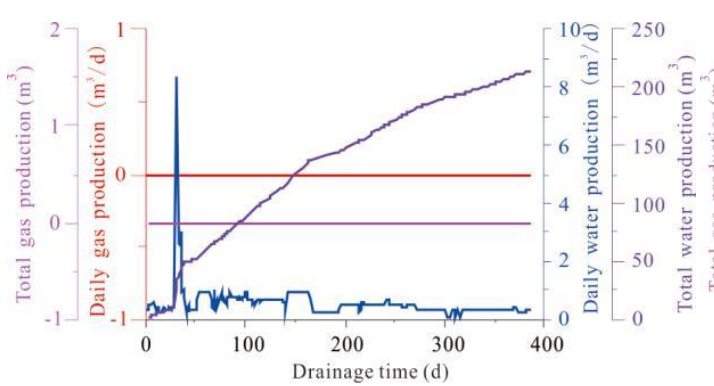

Fig.6-1 DS-20 CBM well drainage curve chart

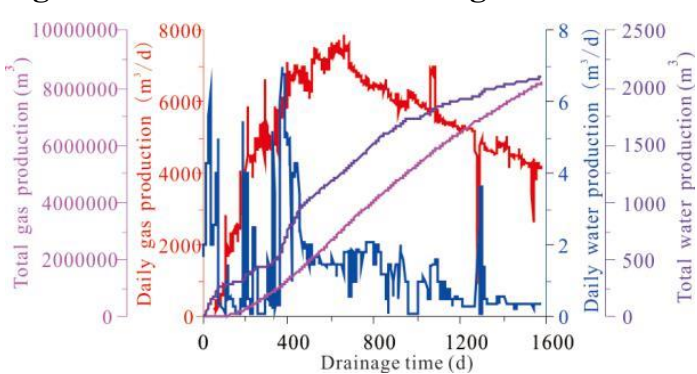

Fig6-3 HC1-10 CBM well drainage curve chart

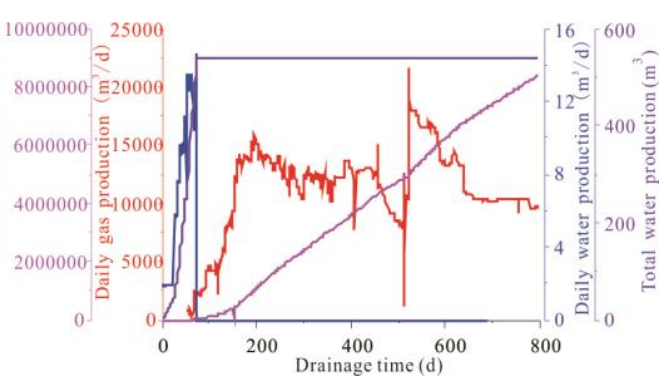

Fig.6-2 DS-21 CBM well drainage curve chart

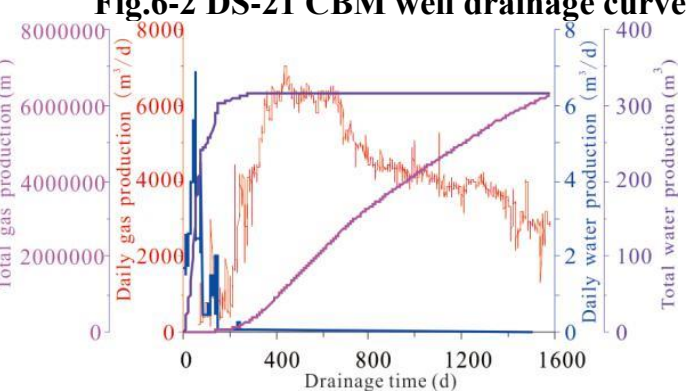

Fig6-4 HC1-7 CBM well drainage curve chart

Fig6 Typical drainage curve of CBM wells in southern Fanzhuang

Typical gas-water production features of zone $I$ is shown in figure $6-1$, the gas-production is 0 $\mathrm{m}^{3} / \mathrm{d}$ and water-production is $0.56 \mathrm{~m}^{3} / \mathrm{d}$, it belong to low gas-water yield CBM wells. This is comprehensive function that negative effects greater than positive effects.

Zone II is intense interface region, figure 6-2 is typical gas-water production features. The maximum daily gas production can up to $11283 \mathrm{~m}^{3} / \mathrm{d}$ and water-production time was only for $71 \mathrm{~d}$, the highest water yield reached to $14.6 \mathrm{~m}^{3} / \mathrm{d}$ and average water production was $7.52 \mathrm{~m}^{3} / \mathrm{d}$. Intense interface region was belong to high gas-production, low water-production well. Under the circumstances of cannot produce gas in later period, it can be seen from figure 5-b that gas yield increased steadily firstly, then remained stably for some time and decreased slightly later, after that up to maximum yield, finally decreased. The curve is typical of double peak production curve. This shows that, the positive effect of mining subsidence area to production of CBM wells is larger than negative effect.

Zone III is weak interface zone, figure 6-3 is typical gas-water production features. gas yield increased steadily firstly, then reached maximum yield, finally decreased. The curve is typical of single peak production curve. The main causes were depressurization and enhanced permeability of mining subsidence area to coal reservoirs as well as high gas content. The daily gas-production of $\mathrm{HC} 1-10$ well is $5392.53 \mathrm{~m}^{3} / \mathrm{d}$ and daily water-production is $1.35 \mathrm{~m}^{3} / \mathrm{d}$, it was belong to middle gas-production, low water-production well.

Zone IV is original coal seam zone and untouched by stress release of mining subsidence area. figure 6-4 is typical production curve of this zone. The daily gas-production of HC1-7 well is $4124.46 \mathrm{~m}^{3} / \mathrm{d}$ and daily water-production is $1.08 \mathrm{~m}^{3} / \mathrm{d}$. with no effect of stress release, the reservoir physical property is bad, it belong to middle gas-production, low water-production well.

\section{Conclusion}

Based on analysis of coal reservoir physical property and $30 \mathrm{CBM}$ development wells near mining subsidence area of Fanzhuang block, the conclusions as follows:

(1) The change of production near mining subsidence area was the coupling results of positive and negative effect, depressurization and enhanced permeability in mining subsidence area changed gas content and permeability of near coal seams, and further controlled productivity of CBM wells.

(2) Permeability of CBM wells near mining subsidence area decreased gradually then stably with the increased distance to mining subsidence area, over $2200 \mathrm{~m}$ is called original coal seam area; gas contents of CBM wells near mining subsidence area increased gradually at first then stably with the 
increased distance to mining subsidence area.

(3) Consider the regular change of permeability near coal seams and gas production, regions near mining subsidence area were divided into 4 zones. Zone I (pressure released zone), which within $400 \mathrm{~m}$ of mining subsidence area, has lower gas yield and water yield, even down to 0 ; The range of distance for zone II (intense interface region) is between $400 \mathrm{~m}$ to $1000 \mathrm{~m}$, daily gas production is three times as large as wells in original coal seam region. CBM wells in zone II is belong to typical "high gas production and low water production" wells, with highest gas production in mining influence area. The range of distance for zoneIII(weak interface region) is between $1000 \mathrm{~m}$ to $2200 \mathrm{~m}$. In zoneIII, gas producing time and water producing time were increased compared with zone II , and gas production is lower than zone II ; the distance range for zoneIV (original coal seam region) is more than $2200 \mathrm{~m}$, gas-water production time of CBM wells is longer than mining influence area, the daily gas production is lower than zone II and zoneIII.

\section{Acknowledgement}

Financial support for this work was provided by the National Major Research Program for Science and Technology of China (No. 2016ZX05044, No. 2016ZX05067, No. 2011ZX05061, No. 2011ZX05034), and the Fundamental Research Funds for the Central Universities of China(No. 2013QNB31, No. 2015XKZD07).

\section{Reference}

[1] Flores R.M.,1998.Coalbed Methane: from Coal Mine Outbursts to a Gas Resource. International Journal of Coal Geology.,1-4.

[2] Law D., Meer L.G.H.V.D., Gunter W.D.,2002. Numerical Simulator Comparison Study for Enhanced Coalbed Methane Recovery Processes, Part I: Pure Carbon Dioxide Injection, SPE 75669 presented at the SPE Gas Technology Symposium held in Calgary, Alberta, Canada.

[3] Scott R.,2002. Field studies of enhanced methane recovery and CO2 sequestration in coal seams World Oil, 9.

[4] Karacan C. Özgen,2013. Integration of vertical and in-seam horizontal well production analyses with stochastic geostatistical algorithms to estimate pre-mining methane. International Journal of Coal Geology 114,96-113.

[5] Qin Y., Yuan L., Hu QT., Ye JP., Hu JM.,Shen BH., Cheng YP., He XQ., Zhang SA., Li GF., Zhang Q.,2012. Status and development orientation of Coal Bed Methane exploration and development technology in China. Coal Science and Technology.10,1-6,(in Chinese).

[6] Fan ZL., Shen BH., Hu BN., Lei Y.,2014. Coalbed methane development and technical access in china coal mining area. Coal Science and Technology.01,44- 49+75, (in Chinese).

[7] Yuan L.,2006. Research on comprehensive mine gas prevention and control technology system in mine with complicated geological conditions. Coal Science and Technology.34(1),1-3,(in Chinese).

[8] Cheng YP., Yu QX.,2007. Development of regional gas control technology for chinese coalmines. Journal of Mining \& Safety Engineering.24(4),383-390, (in Chinese).

[9] Zhao ZY.,2007. Gas Comprehensive mangement on mining protective seam in full mechanized coal face. Coal Technology.26(11),7-78,(in Chinese).

[10] Wu HT.,2011. Study and practice on technology of three-zones linkage 3D coalbed methane drainage in coal mining area. Journal of China Coal Society.36(8),1312-1316,(in Chinese).

[11] Li MX., Zhang C., Zhang SX., Shi B., Wang LL., Cui XR.,2012. Characteristics of production 
of CBM vertical well in Fanzhuang block, Qinshui basin. China Coalbed Methane.03:3-7,(in Chinese).

[12] Li MX., Wang LL., Xin R., Miao Y., Liu YH.,2011. Output characteristics of vertical wells and dewatering control method used in Fanzhuang block of Qinshui CBM filed. China Coalbed Methane.8(1),11-13,(in Chinese).

[13] Wang XH., Lu X., Jiang WD., Xian BA., Wang YL.,2004. Economic evaluation of coalbed gas development in Fanzhuang block, Qinshui coalbed gas field. Natural Gas Industry.24(5),137-139,(in Chinese).

[14] Yao HF.,2009. Coal-bed methane resources and proved reserves in Fanzhuang Block of Qinshui Basin. Fault-Block Oil \& Gas Field.16(4),48-50,(in Chinese).

[15] Lin R., Ni XM., Wang YB.,2012, Prediction of high CBM production area in the Fanzhuang block of the Qinshui basin, Shanxi Province. Geological Journal of China Universities.03,558562,(in Chinese).

[16] Hu QJ, Li MX., Wang LL., Yan L., Liu GW.,2012. Analysis on coalbed methane straight well gas yield curve characteristic of Fanzhuang block. China Coalbed Methane.06,3-7, (in Chinese).

[17] Cao W.,2005. Economic analysis of various exploitation ways in Fanzhuang block of Qinshui coal-bed gas field. Natural Gas Industry. 03,174-176+211,(in Chinese).

[18] Qian MG., Xu JL.,1998. Study on the "O-SHAPE" circle distribution characteristics of mining-induced fractures in the overlaying strata. Journal of China Coal Society.05,20-23,(in Chinese).

[19] Sun PD., Xian XF., Coupled models for coal seam deformation-gas leakage and its applications. Journal of China Coal Society.01,62-66,(in Chinese).

[20] Wu B., Wu YZ., Zhang YD., Miao YG.,2007. Practice of gas drainage in pressure relief area of coal mining face in Chang Cun coal mine. Coal Engineering.12,52-53,(in Chinese).

[21] Wu JG.,2008. Integrated technology of coalbed methane drainage with ground well in Luling coal mine. Coal Geology \& Exploration.01,27-29+33,(in Chinese).

[22] Hu GZ., Wang HT., Li XH., Tu XD., Zhang ZM., Shen YH.,2009. Optimization design on extracting pressure-relief gas of steep inclined up-protective layer with pitching oblique mining. Journal of China Coal Society.01,9-14, (in Chinese).

[23] Jia GL., Mo RH., Lai WQ., Yuan S., Zhang SK.,2016. CBM geological characteristics and exploration and development strategy of Enhong-Laochang exploration blocks, Yunnan Province. China offshore Oil And Gas.(01), 29-34,(in Chinese). 